\title{
Combination Effects of Moringa oleifera Leaf Ethanol Extract and Andrographis paniculata Herb on Blood Glucose Levels and Pancreas Histopathology of Diabetic Rats Induced by Streptozotocin
}

\author{
Annisa Fatmawati ${ }^{*}$, Moch. Saiful Bachri², Laela Hayu Nurani ${ }^{2}$ \\ ${ }^{1}$ Pharmaceutical Study Program, Alma Ata University \\ 2 Faculty of Pharmacy, Ahmad Dahlan University
}

\begin{abstract}
Type 2 diabetes mellitus is a non-contagious disease, can damage the glucose metabolic system in the body, and is characterized by hyperglycemic conditions. Moringa leaves (Moringa oleifera) and Andrographis herbs (Andrographis paniculata) have been studied to have antihyperglycemic activity in diabetic rats. The purpose of this study was to determine the effect of the combination of Moringa leaf ethanol extract (MLEE) and ethanol extract of Andrographis herbs (AHEE) in streptozotocin-induced rats $(45 \mathrm{mg} / \mathrm{kgBW})$. The subjects consisted of 32 rats, divided into 8 groups (1 healthy group and 7 types $2 \mathrm{DM}$ groups). The study was conducted for 4 weeks by measuring blood glucose levels in pre-treatment, day 0 , 14 and 28 with a single MLEE treatment dose of $300 \mathrm{mg} / \mathrm{kgBW}$, single AHEE $300 \mathrm{mg} / \mathrm{kgBW}$, combination of MLEE and AHEE $150+150 \mathrm{mg} / \mathrm{kgBW}, 200+100 \mathrm{mg} / \mathrm{kgBW}, 100+200 \mathrm{mg} / \mathrm{kgBW}$, and gliclazide 5 $\mathrm{mg} / \mathrm{kgBW}$ orally. The results of measurement of fasting blood glucose levels on day 28 showed that administration of gliclazide $5 \mathrm{mg} / \mathrm{kg} \mathrm{BW}$, single-dose MLEE and AHEE, as well as its combination, had significant differences $(\mathrm{p}<0.05)$ compared to the hyperglycemic control group. Pancreatic organ histopathology features in the extract dose group showed that there was a change in the repair of insula Langerhans compared to the hyperglycemic control group which showed necrotic damage due to streptozotocin induction. Combination administration has the same antihyperglycemic effect by single-dose extract in diabetic rats within 28 days, which also restore weight loss to normal.
\end{abstract}

Keywords: Moringa oleifera, Andrographis paniculata, type 2 diabetes mellitus, pancreatic $B$ cell histopathology

\section{INTRODUCTION}

Type 2 diabetes mellitus is a non-contagious disease, can damage the glucose metabolism system in the body, and is characterized by hyperglycemic conditions. Management of type 2 diabetes mellitus therapy uses synthetic drugs, such as gliclazide is known to have many side effects (Sarkar et al., 2011), hence it needs an alternative and mentoring therapy with more natural ingredients. Some of these natural ingredients are Moringa oleifera leaves and bitter herbs (Andrographis paniculata).

Moringa contains flavonoid compounds that can regenerate pancreatic beta cells in diabetic rat test animals (Gupta et al., 2015). Ethanol extract of Moringa leaves can reduce reactive free radicals so that it can reduce oxidative damage in STZ-induced mice (Soliman, 2013). Invivo studies show that terpenoids and flavonoids have hypoglycemic activities (Anyanwu et al., 2014). Quercetin is a flavonoid which has potential antidiabetic activity in ethanol extract of Moringa leaves

*Corresponding author: Annisa Fatmawati

Email : annisafatma20@gmail.com
(Ali et al., 2015). Some research reported the mechanism of quercetin as antidiabetic, such as decreased lipid peroxidation, increased activity of antioxidant enzymes (such as SOD, GPX, and CAT), and decreased intestinal glucose absorption by inhibiting GLUT2 (Vinayagam and Baojun, 2015).

Ethanol extract of bitter leaf is known to have antihyperglycemic activity in STZ-induced diabetic rats and within 28 days was able to restore a decrease in rat body weight to normal (Premanath and Laksmidhevi, 2015), with the contents of diterpenoid compounds and flavonoids (Okhuarobo et al., 2014). Diterpenoid active compounds in A. paniculata such as andrographolide, neoandrographolide, deoxyandrographolide, neoandrographolide and isoandrographolide (Chao and Lin, 2010 in Sari et al., 2015). Andrographolide can reduce insulin resistance (Adriawan et al., 2014). The study of Burhanuddin et al. (2014) states that the combination of Moringa leaves and bitter herbs combined before extraction can reduce blood glucose levels in dexamethasone-induced mice. The quercetin content of the Moringa leaf ethanol extract (MLEE) and andrographolide in 
the sambiloto herb ethanol extract (AHEE) is known to have antidiabetic activity with different mechanisms, so the antidiabetic effect of the combination of Moringa leaves and bitter herbs are needed.

\section{METHODOLOGY Plant Materials}

Fresh Moringa oleifera and bitter (Andrographis paniculata) plants were obtained from Karanganyar, Central Java, and were identified at the Biology University of Ahmad Dahlan University (UAD), Yogyakarta.

\section{The Subject of Antihyperglycemic Model}

Male Wistar Rats were obtained from Departement of Pharmacology, Universitas Islam Indonesia. Streptozotocin diabetes induction (Sigma-Aldrich ${ }^{\circledR}$ ), Gliclazide (Glucodex) and GODPAP blood glucose reagent kit (Diasys). This research has been approved by the Pharmacy Faculty Ethics Committee, Ahmad Dahlan University with No.011801014. Wistar male rats 170-250 grams, age 2-3 month were maintained in the UAD test animal laboratory, in a controlled air conditioner $(\mathrm{AC})$ room $25 \pm 1^{\circ} \mathrm{C}, 12$ hours dark and 12 hours bright. Feed (Comfeed) and animal drinks (aqua) were controlled in a plastic cage covered with wire mesh.

\section{Methods}

Plant Material and Extract Preparation

Plant material for extraction is washed and taken from each part of the moringa leaves and andrographis herbs, dried using an oven at a temperature of $40-60{ }^{\circ} \mathrm{C}$, the dried material is pollinated using a blender. Each dry powder was weighed $\pm 1.5 \mathrm{~kg}$ and then macerated with $70 \%$ ethanol (1:5), stored in a place protected from light for 3 days, macerate separated from the pulp by filtration and residual pulp was remacerated twice. Each mass obtained from filtration evaporated with a rotary evaporator then heated with water bath. Furthermore, the extract was carried out by GC-MS analysis (to ensure there was no alcohol content). GC-MS analysis was carried out in the integrated laboratory of Ahmad Dahlan University by testing each extract (ethanol extract of moringa leaves and ethanol extract of bitter herbs).

\section{Animal Test Model}

The test animal model was induced with a single intraperitoneal streptozotocin (STZ) induction dissolved in citrate buffer $(\mathrm{pH} 4.5)$ at a dose of $45 \mathrm{mg} / \mathrm{kg}$ BW (Premanath \& Laksmidevi, 2015). Hyperglycemic conditions were examined 72 hours after STZ injection by measuring glucose levels in blood samples obtained from rat orbitalis that fasted overnight. rats that have blood glucose levels above $250 \mathrm{mg} / \mathrm{dl}$ are considered diabetic and are used in this study (Jangir \& Jain, 2016). Animal testing rats were divided into eight groups (1 normal group and 7 types 2 DM groups), each group consisting of four rats. Weighing the weight of rats in all test groups was conducted to see the changes that occurred during the study. The study was conducted for 4 weeks by measuring blood glucose levels on pre-treatment, 0,14 , and 28 days with a single dose of gliclazid $5 \mathrm{mg} / \mathrm{kgBW}$ (Saravanan \& Ponnusamy, 2013), MLEE 300 $\mathrm{mg} / \mathrm{kgBW}$, single AHEE $300 \mathrm{mg} / \mathrm{kgBW}$, a combination of MLEE and AHEE $150+$ 150mg/kgBW (Combination 1.5:1.5), $200+100$ mg/kgBW (Combination 2:1) and $100+200$ mg/kgBW (Combination 1:2) orally. On the 28th day, rat surgery was performed, pancreatic organs were taken and histopathological preparations (hematoxylin-eosin) were made at Faculty of Veterinary Medicine, Gadjah Mada University. Analysis statistic by SPSS 16 with Post Hoc Duncan Test.

\section{RESULTS AND DISCUSSION}

The results of GC-MS analysis on MLEE and AHEE did not contain alcohol after tested in the integrated laboratory of Ahmad Dahlan University. This study used male Wistar rats induced intraperitoneal streptozotocin dose of 45 $\mathrm{mg} / \mathrm{kgBW}$ (Premanath \& Laksmidhevi, 2015). The STZ molecular structure is similar to 2-deoxy-Dglucose with replacement in $\mathrm{C} 2$ with the N-methyl$\mathrm{N}$-nitrosourea group, which is a cytotoxic part of STZ in damaging pancreatic beta cells (Goud et al., 2015).

\section{Effects of Combination Extracts on Fasting Blood Glucose Level}

On pre-induction days before being treated with test animals, blood was collected in all rats in each group of rats. Then the test extract was given and blood glucose levels were measured for the calculation of glucose levels day 0 . day 14 and 28 days, with the data found in (Table I). Fasting blood glucose levels (FBGL) on an average pre-induction day there was no significant difference $(p<0,05)$ in all groups, FBGL all rats are in normal condition.

Post-induction day (day 0) of 72 hours after STZ induction showed an increase in FBGL $>250$ $\mathrm{mg} / \mathrm{dl}$. The FBGL hyperglycemic test group had significant differences $(\mathrm{p}<0.05)$ compared to the normal control group (Table I). Day 14 after administration of drugs and extracts of single or combination doses, blood samples were taken. Table I shows that on the 14th day of the gliclazide 
Table I. Average fasting blood glucose level (mg / dL)

\begin{tabular}{cccccc}
\hline \multirow{2}{*}{ Group } & \multicolumn{5}{c}{ Mean \pm SEM $(\mathrm{n}=4)$} \\
\cline { 2 - 6 } & Pre-Induction & \multicolumn{2}{c}{ Day 0 } & Day 14 & Day 28 \\
\hline Normal & $88.46 \pm .77$ & $94.76 \pm .09^{\mathrm{b}}$ & $112.82 \pm .75$ & 8.74 & \pm .12 \\
Control hyperglycemic & $90.86 \pm .98$ & $442.07 \pm 3.71^{\mathrm{aA}}$ & $423.94 \pm 1.15^{*}$ & $409.49 \pm .33^{*}$ \\
MLEE 300mg/kgBW & $85.48 \pm .28$ & $389.38 \pm 5.76^{\mathrm{aA}}$ & $292.35 \pm 0.62^{\mathrm{abB}}$ & $161.12 \pm 0.66^{\mathrm{abC}}$ \\
AHEE 300mg/kgBW & $82.58 \pm .70$ & $391.15 \pm 8.00^{\mathrm{aA}}$ & $299.08 \pm 6.51^{\mathrm{abB}}$ & $156.80 \pm 4.73^{\mathrm{abC}}$ \\
Combination (1.5:1.5) & $85.27 \pm .48$ & $413.10 \pm 8.32^{\mathrm{aA}}$ & $300.92 \pm 8.43^{\mathrm{abB}}$ & $175.64 \pm .83^{\mathrm{abC}}$ \\
Combination (2:1) & $92.78 \pm .14$ & $396.53 \pm .86^{\mathrm{aA}}$ & $238.39 \pm 0.02^{\mathrm{abB}}$ & $145.89 \pm 7.15^{\mathrm{abC}}$ \\
Combination (1:2) & $89.80 \pm .98$ & $399.72 \pm 1.38^{\mathrm{aA}}$ & $322.88 \pm 3.58^{\mathrm{abB}}$ & $127.69 \pm 5.30^{\mathrm{bC}}$ \\
gliclazide 5mg/kgBW & $86.90 \pm .77$ & $392.00 \pm 6.25^{\mathrm{aA}}$ & $126.13 \pm 7.07$ & $21.67 \pm 7.61$ \\
\hline
\end{tabular}

Duncan test: a: significantly different from the normal control group $(p<0.05)$; b: significantly different from the negative control group ( $\mathrm{p}<0.05) ;{ }^{*}$ significantly different from single dose groups; A: significantly different from pre-induction day, B: significantly different from day 0; C: is different from day 14.

Table 2. Average rat body weight (grams)

\begin{tabular}{cllll}
\hline \multirow{2}{*}{ Group } & \multicolumn{4}{c}{ Mean \pm SEM $(\mathrm{n}=4)$} \\
\cline { 2 - 5 } & \multicolumn{1}{c}{ Pre-Induction } & \multicolumn{1}{c}{ Day 0} & \multicolumn{1}{c}{ Day 14} & Day 28 \\
\hline Normal & $190,52 \pm 1,66$ & $199,03 \pm 10,29$ & $205,00 \pm 11.64^{\mathrm{b}}$ & $204,00 \pm 5,34^{\mathrm{aC}}$ \\
Control hyperglycemic & $194,40 \pm 13,08$ & $199,75 \pm 3,01$ & $160,13 \pm 11.26^{\mathrm{a}}$ & $155.93 \pm 1,85$ \\
MLEE 300mg/kgBW & $214,35 \pm 17,87$ & $201,43 \pm 15,69$ & $194,50 \pm 14.73$ & $203,63 \pm 16,53^{\mathrm{aC}}$ \\
AHEE 300mg/kgBW & $222,43 \pm 8,69$ & $208,23 \pm 6,58$ & $198,50 \pm 8.65$ & $201,00 \pm 10,60^{\mathrm{aC}}$ \\
Combination (1.5:1.5) & $209,53 \pm 12,97$ & $197,05 \pm 6,92$ & $199,88 \pm 17.87$ & $200,00 \pm 17,66^{\mathrm{aC}}$ \\
Combination (2:1) & $188,52 \pm 11,17$ & $192,40 \pm 4,74$ & $191,75 \pm 14.42$ & $215,13 \pm 8,34^{\mathrm{aC}}$ \\
Combination (1:2) & $201,70 \pm 11,09$ & $197,45 \pm 4,73$ & $189,50 \pm 6.74$ & $210,25 \pm 5,43^{\mathrm{aC}}$ \\
Gliclazide 5mg/kgBW & $215,60 \pm 10,11$ & $210,38 \pm 3,79$ & $235,13 \pm 16.75^{\mathrm{b}}$ & $231,38 \pm 16,97^{\mathrm{bC}}$ \\
\hline
\end{tabular}

Duncan test: a: significantly different from the normal control group $(\mathrm{p}<0.05)$; b: significantly different from the negative control group $(\mathrm{p}<0.05) ;{ }^{*}$ significantly different from single dose groups; A: significantly different from pre-induction day, B: significantly different from day 0; C: is different from day 14.

group, all doses of the test extract experienced a significantly different decrease in FBGL ( $p<0.05)$ compared to the hyperglycemic group. The group administering gliclazide $5 \mathrm{mg} / \mathrm{kg}$ BW showed a decrease in FBGL which was not significantly different ( $p>0.05)$ with the normal control group.

Measurement of 28th day (4th week) KGDP of MLEE and AHEE combination doses, there was no significant difference $(\mathrm{p}<0.05)$ compared to single group MLEE $300 \mathrm{mg} / \mathrm{kgBB}$ and $300 \mathrm{mg} / \mathrm{kgBB}$ AHEE. The group of MLEE $100 \mathrm{mg}+$ AHEE combination dose $200 \mathrm{mg} / \mathrm{kgBB}$, significantly decreased KGDP compared to the negative control group and did not differ significantly from normal controls. This is in accordance with the study of Burhanuddin et al., (2014), that the combination of Moringa leaves and bitter herbs were mixed during extraction with a ratio (2: 8), (5: 5) and (8: 2) capable of reducing KGDP in mice dexamethasoneinduced.

\section{Effects of Combination Extracts on Rat Body Weight}

Rat body weight was weighed before induction of DM with streptozotocin and each blood sampling to monitor its increase and decrease (Table II). Pre-induction days showed no significant differences $(p>0.05)$ in all test groups (Table II). After STZ induction, weighing on day 0 had not shown a significant weight difference $(p>0.05)$ in all groups. Profile of changes in rat body weight on day 14 (Table II), showed that the weight of the negative control group, positive control and single and combination dose extracts significantly decreased weight compared to the normal control group ( $\mathrm{p}<0.05)$.

Changes in body weight on day 28 (Table II), showed that the single and combination extract test groups had increased and did not differ significantly ( $p>0.05$ ) from the normal control group. The hyperglycemic control group had 


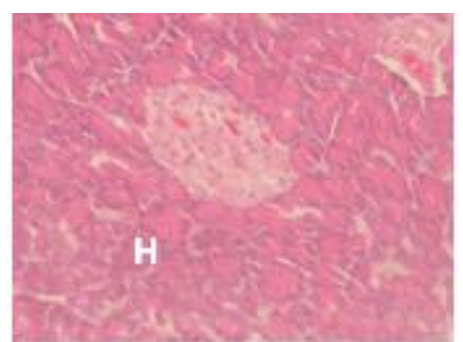

Normal

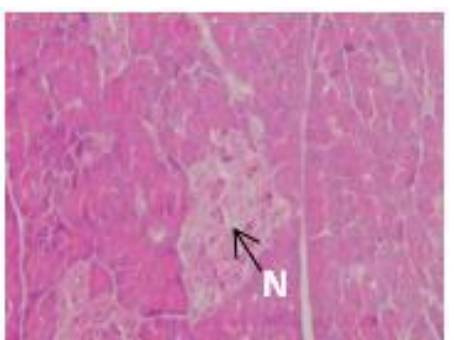

MLEE 300mg/kgBW

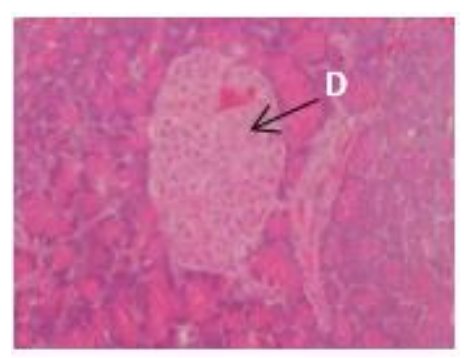

Gliclazide 5mg/kgBW

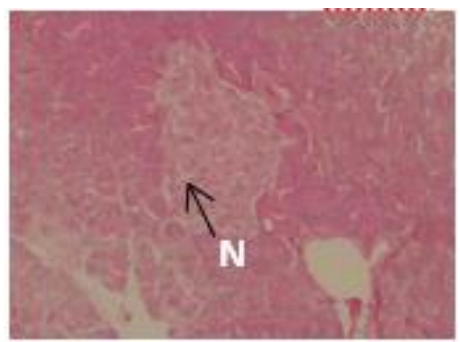

AHEE 300mg/kgBW

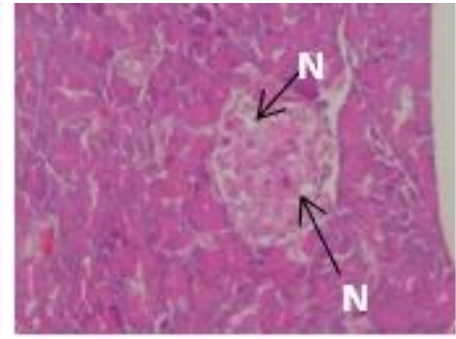

Control hyperglycemic

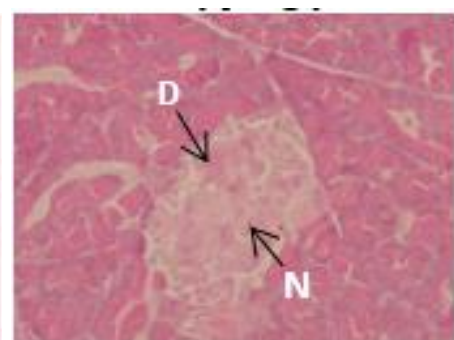

Combination (1.5:1.5)

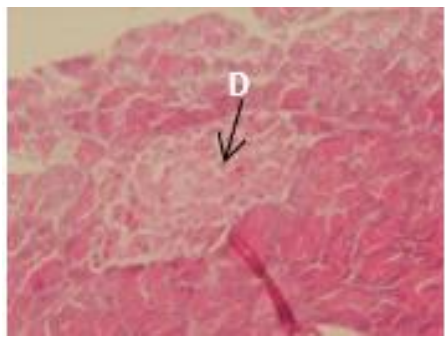

Combination $(2: 1)$

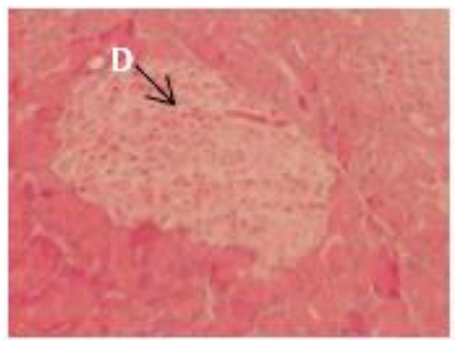

Combination (1:2)

Information: N: Necrosis; D: Degeneration; H: There are no changes

Figure 1. Photograph of rat pancreatic tissue preparations with HE staining

significantly different weight loss $(\mathrm{p}<0.05)$ with the normal control group. The gliclazide group showed significant changes in body weight $(\mathrm{p}>$ 0.05 ) with the normal control group, single dose and combination test extract groups. Single extract and combination test groups, there were significant differences $(p<0.05)$ compare with the hyperglycemic control group. Streptozotocininduced rats become diabetic, characterized by severe weight loss. Weight loss of diabetic mice occurs due to loss or degradation of structural proteins to provide amino acids for gluconeogenesis during insulin deficiency resulting in muscle wasting and weight loss. (Premanath and Laksmidevi, 2015).

\section{The Effect of Combination Extract on Pancreatic Histopathology}

After 4 weeks, the rat pancreas was taken and tissue cut, tissue preparation and hematoxylineosin (HE) were stained. Histopathological preparations were observed under a microscope with 40x magnification (Figure 1).

Diagnosis of pancreatic histopathology preparations in the normal group (Figure 1) showed no changes in insula langerhans cells. The condition of the cell is still intact, round, pale, surrounded by fine fibers, has no channels, with many blood vessels for the distribution of pancreatic gland hormones. Fine reticular fibers surround each langerhans insula and separate them from adjacent acetic cells (Nesti, 2015).

Histopathological examination of the untreated pancreatic langerhans in the pancreas of STZ diabetic rats showed severe changes in necrosis, degenerative and atrophy. The shrinking langerhans islands show decreased density, cell granulation and vacuolization (Premanath and Laksmidhevi, 2015).

The condition of gliclazide of insula langerhans shows degeneration (cells experiencing swelling and unclear boundaries 
between cells) and necrosis. Figure 1 shows that with gliclazide treatment, langerhans insula cells undergo improvement and approach normal conditions in degenerated cells. Dosing of single or combination extracts in STZ-induced mice can improve pancreatic beta cells. Degenerative damage is reversible, while necrosis damage is irreversible (Premanath and Laksmidhevi, 2015). Moringa contains flavonoid compounds that can regenerate pancreatic beta cells in diabetic rat test animals (Gupta et al., 2015). Ethanol extract of Moringa leaves can reduce reactive free radicals, it can reduce oxidative damage in STZ-induced mice (Soliman, 2013). Invivo studies show that terpenoids and flavonoids have hypoglycemic activities (Anyanwu et al., 2014).

Several studies have reported the mechanism of quercetin as an antidiabetic, such as decreased lipid peroxidation, increased activity of antioxidant enzymes (such as SOD, GPX, and CAT), inhibition of PI3K activation and decreased intestinal glucose absorption by inhibiting GLUT2 (Vinayagam and Baojun, 2015). The mechanism of andrographolide as an antidiabetic by reducing insulin resistance (Adriawan et al., 2014) and andrographolide are insulin secretagogues (Wibudi, 2006). This combination study shows the existence of complementary effects (mutually supportive effects towards one indication with a different mechanism) between MLEE and AHEE.

\section{CONCLUSION}

The combination dose of Moringa leaf ethanolic extract and Andrographis Herb ethanolic extract, had the same effect as a single dose of each extract, able to reduce FBGL, restore body weight and repair pancreatic beta cells on day 28 in STZ induced rats.

\section{ACKNOWLEDGMENTS}

The author would like to thank the MoringaAndrographis research team and the employees of the UAD Pharmacy Laboratory who provided assistance so that this research proceeded.

\section{REFERENCES}

Adriawan, Ignatius Ryan, Mohamad Andrie, Rina Susilowati, Suwidjiyo Pramono and Agung Endro Nugroho. 2014. Evaluasi Efek AntiDiabetes Melitus Ekstrak Terpurifikasi Andrographis paniculata (Burm.f.) Nees dan Andrografolid Dengan Parameter Indeks HOMA-IR. Trad. Med. J., January 2014 Vol. 19(1), p 19-23 ISSN : 1410-5918

Ali, Fahmy T., Nahla S. Hassan dan Rehab R. Abdrabou. 2015. Potential activity of Moringa Oleifera leaf extract and some active ingredients against diabetes in rats. International Journal of Scientific \& Engineering Research, Volume 6, Issue 5

Anyanwu, Anthony Chinedu., Salako Olanrewaju Alani., Adeyemi Olufunmi Olaide. 2014. Effect of the Ethanolic Leaf Extract of Moringa oleifera on Insulin Resistance in STZ Induced Diabetic Rats. Journal of Plant Sciences. Vol. 2, No. 6-1, 2014, pp. 5-12.

Burhanuddin, Marianti A. Manggau, Faisal Attamimi. 2014. Combined Effect Extract Leaves of Moringa (Moringa Oleifera) and Sambiloto Herbs (Andrographis Paniculata) Blood Glucose Levels Lowering Male Mice (Mus Musculus) Effects of Dexamethasone. JST Kesehatan Januari 2014, Vol.4 No.1: 17 24

Goud, Busineni Jayasimha. 2015. "Streptozotocin A Diabetogenic Agent in Animal Models". IJPPR.Human, 2015; Vol. 3 (1): 253-269.

Gupta, Arti, Navin R Sheth, Sonia Pandey and Jitendra Singh Yadav. 2015. Determination of Quercetin a Biomarker in Hepatoprotective Polyherbal Formulation through HPLC. J Chromatogr Sep Tech 2015, $6: 6$

Jangir, Ram Niwas dan Gyan Chand Jain. 2016. Antidiabetic And Antioxidant Potential of Hydroalcoholic Extract Of Moringa oleifera Leaves In STZ-Induced Diabetic Rats. ejpmr, 2016,3(9), 438-450

Nesti, Dela Ria. 2015. Morfologi, Morfometri Dan Distribusi Sel Imunoreaktif Insulin Dan Glukagon Pada Pankreas Tikus (Rattus norvegicus) Obesitas. Tesis, Faculty of Veterinary Medicine, Gadjah Mada University.

Okhuarobo Agbonlahor, Joyce Ehizogie Falodun, Osayemwenre Erharuyi, Vincent Imieje, Abiodun Falodun, Peter Langer. 2014. Harnessing the medicinal properties of $\mathrm{A}$. paniculata for diseases and beyond: a review of its phytochemistry and pharmacology. Asian Pac J Trop Dis 2014; 4(3): 213-222

Premanath, Ramya \& Lakshmidevi Nanjaiah. Antidiabetic and Antioxidant potential of A. paniculata Nees. Leaf ethanol extract in STZ induced diabetic rats. J App Pharm Sci, 2015; 5 (01): 069-076.

Sarkar, Ananya, Ajay Tiwari, Parminder S. Bhasin and Moloy Mitra. 2011. Pharmacological and Pharmaceutical Profile of gliclazide: A Review. 2011. JAPS 01 (09); 2011: 11-19

Saravanan, Ganapathy and Ponnusamy Ponmurugan. 2013. S-allylcysteine Improves STZ-Induced Alterations of Blood 
Glucose, Liver Cytochrome P450 2E1, Plasma Antioxidant System, and Adipocytes Hormones in Diabetic Rats. Int J Endocrinol Metab. 2013 Oct; 11(4)

Sari, K. R. P., Sudarsono and Nugroho, A. E. Effect of herbal combination of Andrographis paniculata (Burm.f) Ness and Gynura procumbens (Lour.) Merr ethanolic extracts in alloxan-induced hyperglycemic rats. IFRJ 22(4): 1332-1337 (2015)

Soliman GZA. Anti-diabetic activity of dried Moringa oleifera leaves in normal and streptozotocin (Stz)-induced diabetic male rats. Indian J Appl Res, 2013; 3(9): 18-23.

Wibudi, Aris. 2006. Mekanisme Kerja Sambiloto (Andrographis paniculata) Sebagai Antidiabetes. Disertasi. Departemen Biologi, Sekolah Pasca Sarjana, Institut Pertanian Bogor.

Vinayagam, Ramachandran dan Baojun Xu. 2015. Antidiabetic properties of dietary flavonoids: a cellular mechanism review. Nutrition \& Metabolism (2015) 12:60. Bio Med Central. 